\title{
Community-Based Management of Coastal Damage In Buleleng
}

\author{
by \\ I Gede Astra Wesnawa, Putu Indra Christiawan \\ Department of Geography Education, Undiksha,Singaraja
}

\begin{abstract}
Abstrak:- This research executed in Coastal North Sub-Province Buleleng, Bali, during two year. First year, with aim to to study: (1) how natural coastal characteristic of environmentaldamage coastal area in SubProvince Buleleng?, (2) how environmental damage storey;level of coastal area in Sub-Province Buleleng?, (3) how role of society in management of coastal area?. By virtue of district population swampy forest owning coast, hence selected by 3 district deputizing Sub-Province Buleleng that is Buleleng West taken sample District of Seririt, Middle Buleleng deputized by District of Buleleng and Buleleng East District Kubutambahan. Three the area selected by purposive with consideration that in the area its coast at most experiencing of good damage effect of by coastal abrasion and also human being interference in exploiting resource exist in north coastal seaboard of Bali. Data which collected in this research cover primary data and scoundare data, collected by using data compiler instrument. Data analysis executed by using descriptive analysis qualitative. Result of research show: (1) natural coastal characteristic environmental damage is coast formed by marin erosion and fluvial, (2) environmental damage storey;level make a move from light until, storey;level happened in coastal area Sub-District Seririt, (3) role of society in management of coastal area in the form of self-supporting in handling and reclamation damage of coastal area by planting fast crop of abrasion like: screw pine, waru, and camplung.
\end{abstract}

Keyword: coastal characteristic, damage storey; level, management

\section{INTRODUCTION}

Forestry Statistical Data based on the province of Bali (2002) broad critical land inside and outside of the forest area is $286,938.00$ ha or $50.9 \%$ of the land area of Bali. Critical land areas are broad enough of Karangasem and Buleleng Regency, Jemberana. Based on the letter of Director General RRL No. 412/VRKT/1997 regarding criteria for the determination of critical land, then the land in Bali, which belongs to the highly critical 5,213 ha or $1,82 \%, 10 \%$, somewhat critical criticalcritical potential $36.81 \%$ and $51.59 \%$ of the total critical land in Bali (Balinese Build Data, 2003). From the description above it appears that the damage to the land in this case include also the coast and beach. The damage raises the real ecological changes caused by the errors in land management (Astra, 2007). In the environmental components - components abiotic, biotic and culture (ABC Environment) as the flow of mattercan not run naturally. Appropriate authorities undertake integrated environmental management to preserve environmental functions in accordance with the Law No. 32 in 2009. The utilization of the resources thus took place without regard to the components of the environment, who also realized that the public are utilizing these resources did not understand how environmental management should be done.

In this connection, the authorities can not wash its hands, given as the government should make efforts for the welfare of society without compromising the land and the environment. However, with the enactment of Law No. 22 of 1999 on Regional Autonomy, very ironic, because the district / city governments feel they have the authority to manage and use their environment for the prosperity of its people. Furthermore, it allows each district / city to manage available resources in the region in an effort to increase regional revenue that is done partially by administrative boundaries and not based on natural boundaries landscape. This brings disastrous impact on the environment and the criticality of the resource areas that ultimately have an impact on the quality of human life (SuratmanWoro, 2004).

In conjunction with critical land, Buleleng regency which has the longest coastline on the island of Bali $(159 \mathrm{~km})$ experienced problems associated with damage to the beach. Damage to the beach in the area in between coastal erosion and the absence of a green belt, such as that of the few places on the south coast of Bali. The villages in Buleleng damaged beach among Bukti, Air Sanih, Sangsit, Penarukan, Singaraja, KampungBugis, KampungBaru, SegaraPenimbangan, Tukadmungga, Kalibukbuk, Gondol,Pulaki, and Tembok. In the last decade the numbers of abrasion suffered drastic surge. 1987 abrasion $6.50 \mathrm{~km}$ long coast and in 2000 to $19.15 \mathrm{~km}$ (Security Project Bali Beach, Bali 
In addition to the continuing impact abrasion is damage to coral reefs and other microbial life. For that we need a comprehensive review to ensure the sustainability of coastal ecosystems and the beach as life support in the future. Furthermore, it is known that the characteristics of landforms along the beach is a landform marinBuleleng, alluvial and fluvial (Astra, 2010). The landforms formed by sedimentation of matter good that comes from the land and from the sea. The process takes place continuously, although the nature of the physical environment has the ability to repair themselves. However, still there is damage to the beach, and if this condition persists about in a relatively short time will have negative impacts on the increasingly complex in a coastal environment, such as: disruption of marine life, reduced the natural beauty of the beach, and people can not take advantage of the beach for further socio-cultural activities into a disaster (Astra, 2014).

Another cause damage to coastal areas and beaches of which is not yet its integrated management of coastal areas, beaches and the sea, because of the unavailability of adequate data and information for decisionmaking process. Therefore, it is necessary to study intensively to support the mapping of areas prone to damage due to abrasion and management models, particularly in the North Beach area of Bali.

Directing the conduct of intensive study of the necessary formulation of several research questions such as the following:(1) how natural coastal characteristic of environmental damage coastal area and coast in SubProvince Buleleng?, (2) how environmental damage storey;level of coastal area and coast in Sub-Province Buleleng?, (3) how role of society in management of coastal area?. The purpose of this study are: a) to describe the characteristics of the coastalKebupatenBuleleng who have suffered environmental damage caused by abrasion, b) identify the extent of damage and the location of the coastal in Buleleng, c) examines the role of the community in the management of coastal.

\section{RESEARCH METHOD}

Landform survey design approach used in this study includes three stages (Sugiono, 2016). The first stage is pre-field activities were conducted with the literature study related to the topic of research, secondary data collection, preparation of matters and research tools as well as the designation of the sample taking into account the damage to the coastal environment and coastal, landscape uniqueness and scarcity biota. The second stage is the preparation of the base map as a map of the field work of the RBI maps, field work performed by the field orientation and interviews with local officials on the coast were damaged, observations and direct measurements in the field and interviews with local people about the environmental setting early, and Stage the third is a post-field activities in the form of data analysis.

Based on population distribution district that has a beach, then selected three representative districtBulelengBuleleng West is the District of samples taken Seririt, Central BulelengBuleleng represented by the District and Eastern District of BulelengKubutambahan. Three areas were selected purposively with consideration that the beaches in the area most damaged, either as a result of coastal erosion and human intervention in utilizing existing resources in coastal areas. The data collected in this study included primary data and secondary data, collected using a data collection instrument. Data analysis was conducted using qualitative

\section{RESULTS AND DISCUSSION}

\section{Results}

\section{Characteristics Coast who have suffered environmental damage}

Based on the study of aspects of geomorphology, landscape restrictions coastal area is an area that starts from the zone until the wave broke over the region. Wave rupture zone is a zone near the coast that extends parallel to the coastline, along the zone of the wave starts to break white foam rolling and forming thud onto the beach. The outbreak of the waves caused by the clash wave base in shallow zones due to the slope of the seabed.The distance the waves broke zones for each place is different, depending on the slope of the seabed and the seabed matter. Further behind this shallow zone will be found of the coastal zone which is the area bounded by the waters of the lowest tide line up to the highest tide line.

In the coastal area of Buleleng regency, especially in some coastal areas, such as the Coastal District of Buleleng, District and Sub-District KubutambahanSeririt, an accumulation of sand from the disintegration of rocks carried by the waves to the shore. In coastal areas with sand matter distribution pattern of accumulation of sand matter follows the pattern of the bay, forming a pocket. The rear part of alluvial plains. Based on the concept of measurement in the field, then the distance ecosystems coastal area of Buleleng varies between 5 meters and 50 meters, starting from the rupture zone of waves up alluvial directly opposite the beach. The beach is included in the coastal area ecosystem in the study area Buleleng, which is now being pursued by planting mangrove conservation as well as by installing a gabion stone. Coastal ecosystems research area is an alluvial plain, which along its shores planted with hibiscus, ketapan and camplung.

Assessment of coastal area,can not be separated from coastal typology classification. To determine coastal typology Shepard in the King (1972) based on three main aspects, namely: coastal morphology, constituent matter and the main process to affect the formation of coastal areas. Based on these aspects, the 
coastal areas are grouped into primary and secondary coast. Coastal primers controlled by terrestrial processes, such as erosion, deposition, volcanic and diastrofisme. Coastal secondary is formed by the action of organisms such as the formation of coral reefs and due process of the marina or wave activity. Furthermore, the primary coastal regrouped into 4 typologies, namely: (a) land erosion coasts, (b) sub-aerial deposition coasts, (c) volcanic coasts, (d) structurally shaped coasts.

Coastal secondary grouped into three typologies that coastal erosion due to waves, coastal areas due to the deposition of marine and coastal due to the organism. Typology in detail can be explained as follows: (a) coastal erosion waves are coastal formed by wave activity, which may be patterned straight or irregular, depending on the composition of the rocks making up, as in the process of erosion or abrasion waves on the coastal cliff, ( b) marine deposition coast is a coast formed by the deposition of sediment mattermarin, included in this category is the coast with a barrier, such as: barrier beaches, barrier islands, and (c) coast built by organisms are coastal formed by the activity of an animal or plant including coral reefs formed by algae and oister or plants such as mangrove or marsh grasses. Coastal is commonly found in tropical regions. Based on the above classification, the study area in Buleleng grouped into secondary coastal typology, namely coastal erosion or abrasion wave wave.

The dynamics of exogenous geomorphological processes caused by waves and wind energy, causing forms of primary coastal typology locally experienced growth. Based on the observations and measurements in the field, the characteristics of the coastal area in the district of Buleleng can be described as follows.

Table 1Characteristics of Coastal Region of Buleleng

\begin{tabular}{|c|c|c|}
\hline \multicolumn{2}{|c|}{ Component of NaturalResources } & Descriptions of CoastalAreas \\
\hline \multirow[t]{3}{*}{ Resources } & Geomorphology & $\begin{array}{l}\text { The topography of the rampsSingaraja City } \\
\text { area constituent rocks are Pliocene-aged } \\
\text { volcanic activity report results resen from } \\
\text { young to old - namely Sharpening formations, } \\
\text { consisting of lava, tuff and pumice } \\
\text { breksisedimentary PuraPonjok Batu }\end{array}$ \\
\hline & Land & $\begin{array}{l}\text { Regosol soil brownish gray with ash stem } \\
\text { rocks volkanintermedier and homogin profile, } \\
\text { rough texture, loose soil and sand levels } 80 \% \\
\text { as well as sensitive to erosion and latosol } \\
\text { yellowish brown }\end{array}$ \\
\hline & Land Use & $\begin{array}{l}\text { Beaches (Beach port of Buleleng with floating } \\
\text { restaurant) tourist area is equipped with } \\
\text { supporting facilities like lodging, restaurants } \\
\text { and bars, parking). The use of land for } \\
\text { agriculture (dominant wet land) and } \\
\text { plantations (dominant dry land). }\end{array}$ \\
\hline \multirow[t]{2}{*}{$\begin{array}{l}\text { Biological } \\
\text { resources }\end{array}$} & Flora & 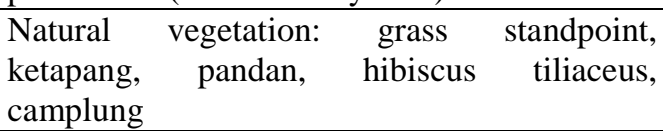 \\
\hline & Fauna & Domestic animals: dogs, birds, cattle, goats. \\
\hline \multirow[t]{3}{*}{$\begin{array}{l}\text { Water } \\
\text { resources }\end{array}$} & Climatology & $\begin{array}{l}\text { The average rainfall is } 1280.30 \mathrm{~mm} / \text { year. } \\
\text { The average temperature is } 26.9^{\circ} \mathrm{C} \\
\text { Type E-climate (a bit dry). }\end{array}$ \\
\hline & $\begin{array}{l}\text { Groundwater } \\
\text { surface water }\end{array}$ & $\begin{array}{l}\text { The taste of fresh water, colorless and } \\
\text { odorless. Water from the PDAM of the shelter }\end{array}$ \\
\hline & Oceanography & $\begin{array}{l}\text { Wind speed Ripple large waves, the waves } \\
\text { small elongated } \\
\text { Wave height of } 1-1.5 \mathrm{~m} \text { wave with period } 6 \\
\text { times permenit }\end{array}$ \\
\hline \multirow[t]{2}{*}{$\begin{array}{l}\text { Human } \\
\text { Resources }\end{array}$} & Population & $\begin{array}{l}\text { Settlements along the coast, with the quality } \\
\text { of substandar. } \\
\text { Dominant population livelihoods of fishermen } \\
\text { and farmers }\end{array}$ \\
\hline & Culture & $\begin{array}{lccc}\text { Places of } & \text { worship } & \text { (temples), } & \text { such as } \\
\text { PuraSegara, } & \text { Buddhist } & \text { temples } & \text { (port of } \\
\text { Buleleng } & \text { in } & \text { KampungBugis), } \\
\text { PuraSegaraPenimbangan }\end{array}$ \\
\hline
\end{tabular}


The Primary Data Analysis Sources: 2015

Based on the characteristics of the coastal areas of Buleleng, damage on aspects of coastal erosion geomorphology are scattered throughout the area. Damage to the beach backed by human activities in coastal use for tourism and other economic activities. Natural vegetation has begun to decrease, so that the ecological function of the plant does not appear.

Relatively large waves mainly occur in the west. According to information that the wave that occurred in the beginning of January to more than 1.5 meters. The wave coincided with the tide, so that it can reach far into the plains and cause a lot of damage to the housing of the population, damage to the beach terrace. Disclosure of the beach because of rare coastal vegetation resulting hit by a wave of various directions which resulted in damage to the beach. Coastal protective shield in the form of artificial terraces building will not last long with wave action.

\section{The level of damage to the beach and the location of the Buleleng}

Damage due to coastal erosion and abrasion the waves in Buleleng Regency is very potential, even information from Department of Marine Buleleng Regency released information that the length of the coast in Buleleng Regency which had suffered damage of not less than $5 \mathrm{~km}$. Abrasion and erosion of the wave which resulted in damage to coastal land was supported by an open, without any protective plants.

Table 2The Extent Of Damage Due To Abrasion Beach Beaches

\begin{tabular}{|l|l|l|l|l|}
\hline No & \multicolumn{1}{|c|}{ Lokation } & \multicolumn{1}{|c|}{ Large } & $\begin{array}{l}\text { the extent } \\
\text { of damage }\end{array}$ & \multicolumn{1}{|c|}{ Information } \\
\hline 1 & Kubutambahan & $\begin{array}{l}<10 \\
\text { meter } \\
\text { (local) }\end{array}$ & light & $\begin{array}{l}\text { There physical building form of } \\
\text { artificial terraces and natural buffer in } \\
\text { the form of hibiscus plants, ketapang } \\
\text { and camplung }\end{array}$ \\
\hline 2 & Buleleng & $\begin{array}{l}<10 \\
\text { meter } \\
\text { (local) }\end{array}$ & light & $\begin{array}{l}\text { physical buildings form artificial } \\
\text { terraces of stone to resist the violent } \\
\text { crushing waves }\end{array}$ \\
\hline 3 & Seririt & $\begin{array}{l}10-100 \\
\text { meter } \\
\text { (local) }\end{array}$ & moderate & $\begin{array}{l}\text { Characteristics of the eroded sand } \\
\text { beaches and hibiscus planting efforts }\end{array}$ \\
\hline
\end{tabular}

Based on Table 2, it can be seen that Seririt Beach is an area that suffered moderate damage, seen from the eroded area of between 10-100 meters locally. While Kubutambahan and Buleleng including mild group, because of the eroded area of less than 10 meters. Judging from coastal erosion in the area of research, there have been efforts to minimize abrasion. However, scour the sea waves resulted terraces fitted stone damage. In mild abrasion areas that have made efforts to plant Waru, Ketapang and Camplung as retaining abrasion.

Coastal erosion into the kind of disaster that took place yesterday in the North Coast of Bali.This incident needs to be known to cause a major factor, so it can be cultivated naturally conservation.Based on the observations and measurements in the field shows that coastal erosion in the study area caused by coastal currents which attack the beach, resulting in the removal of beach matter. This factor must be controlled so as not to erode the beach. Control efforts done artificially with terracing stone placed along the beach at KampungBugis and Kubutambahan. These efforts are in fact temporary, given a geomorphological natural ability to repair themselves. It will appear on the core damage caused by the activities mounted macro and micro benthic life that exist along the coast. Thus, the efforts made in the handling of damages will not last long, if not followed by the surrounding land conservation efforts.

Level of vulnerability to disasters beach on the North Coast Buleleng, grouped into very vulnerable, prone, and somewhat vulnerable. The indicators used are the waves, ocean currents, vegetation, and buildings

Table 3The level of Insecurity in areas of Coastal Disasters Research by 2015

\begin{tabular}{|l|l|l|l|l|}
\hline $\begin{array}{c}\text { The level of } \\
\text { vulnerability }\end{array}$ & \multicolumn{1}{|c|}{ Landform unit } & $\begin{array}{c}\text { The type of } \\
\text { damage }\end{array}$ & \multicolumn{1}{|c|}{ Affectedareas } & \multicolumn{1}{c|}{ Information } \\
\hline \multicolumn{1}{|c|}{$(1)$} & \multicolumn{1}{|c|}{$(2)$} & $(3)$ & \multicolumn{1}{c|}{$(5)$} \\
\hline $\begin{array}{l}\text { VeryVulnerabl } \\
\text { e }\end{array}$ & M4 (coral reefs) & Abrasion & Seririt & $\begin{array}{l}\text { Artificial terraces abrasion } \\
\text { by the waves }\end{array}$ \\
\hline Vulnerable & M3 (beach) & Abrasion & - & - \\
\hline
\end{tabular}




\begin{tabular}{|l|l|l|l|l|}
\hline $\begin{array}{l}\text { Rather } \\
\text { Vulnerable }\end{array}$ & F2 (alluvial plain) & $\begin{array}{l}\text { Abrasion, } \\
\text { sedimentati } \\
\text { on,instrutio } \\
\mathrm{n}\end{array}$ & $\begin{array}{l}\text { KampungBugisan } \\
\mathrm{d} \\
\text { Kubutambahan }\end{array}$ & $\begin{array}{l}\text { Sedimentation is quite high } \\
\text { due to a river estuary / } \\
\text { TukadBanyuning which } \\
\text { empties into the harbor } \\
\text { Buleleng (KampungBugis) }\end{array}$ \\
\hline
\end{tabular}

Based on Table 3, it can be seen that the Turkish Penarukan including highly vulnerable areas, due to the rocky beach terrace and sand were damaged by the waves quite heavy, this is indicated by the foundation in the form of artificial terraces which suffered heavy damage from coastal erosion. While the beach KampungBugis and including Kalibukbuk somewhat vulnerable, because in addition to the erosion, sedimentation and intrusion of sea water is strong enough lead to coast were damaged, although it still includes a light group. This is when left in a relatively short period of time can lead to more damage. Efforts have been made is the mangrove planting / mangrove in Penarukan Beach, and tree maintenance Waru, Camplung and Ketapang in KampungBugis, Tukadmungga, and Kalibukbuk.

\section{The role of communities in the management of coastal and beach}

The role of communities in the management of coastal and beach in Buleleng shown by the self-help efforts of local communities such as damage caused by the blows of a tidal wave that hit the temple building in North Beach Buleleng.Another form of participation coastal planting of cover crops, such as hibiscus plants, camplung, and canging. As good citizens, people must have a high concern about the preservation of the coastal environment in accordance with their respective capabilities. The role of communities in managing coastal damage carried out in the area of research through the preservation of the sea and the beach.

Sea as a natural resource potential. Damage to marine life and beaches are caused due to human activity. Decision-sand beaches, coral reefs, the destruction of mangroves, is human activities that threaten the sea and the beach. Abrasion that threaten the coast has caused the loss of mangrove forests around the beach which is a natural barrier against the onslaught of the waves.In connection with this, the role of the people shown in the study area are: (1) undertake the reclamation by planting of mangroves in the area around the beach, (2) prohibits the taking of coral reefs around the coast and on the seabed, because the reef is fish habitat and marine plants, (3) prohibit the use of explosives and other chemicals in fishing, and (4) prohibits the use of trawl nets to catch fish. As a result of the destruction of the coastline can influence the various sectors, such as tourism, maritime transport, the existence of productive land, biodiversity, to shift borders.

Conditions beach in Buleleng who suffered damage can not be separated from the lack of budget allocation for security in the beach, there are no regulations governing the implementation of coastal protection and coastal security that have been implemented are not in accordance with the characteristics of the beach. This is coupled with the Law No. 27 Year 2007 on Coastal and Small Islands which has not been optimally facilitate securing the shoreline.

In connection with this, then it is necessary to begin to instill awareness of the importance of shoreline to support coastal living, given the number of people living in coastal areas and derive their life in coastal very big (30\%), as shown sitting floor food grilled fish on the beach Buleleng by installing a bamboo to withstand the onslaught of ocean waves.

\section{DISCUSSION}

\section{Characteristics of the coast has suffered environmental damage due to abrasion}

Buleleng regency beach lapped by sand matter interspersed with the Tertiary age sandstones, conglomerates, and tuffvolkan. Buleleng coastal morphology showed similarities to slope gently sloping beach, which is the result of the erosion process. This beach can be said that not many vegetated beach, because the beach is narrow and rocky as it appears in the beach Kubutambahan, quite difficult to develop mangrove plants. However, it is found also on the coast is likely to develop mangrove, although the area is not extensive. While the beach in KampungBugis already covered by an artificial construction, such as concrete to withstand the abrasion rate. Salvatore, et al, (2015) flow characteristics influenced by tides, generally when the water retreating measured current speed is faster than when the water is moving tide. The beach is not protected by cover crops will accelerate the process of building eroded concrete.In geomorphological, natural ability to repair themselves. By building a concrete form in an attempt to resist abrasion in coastal areas, is a temporary effort. This can be explained because there are coastal marine life such as micro and macro benthos that any time would undermine the existing concrete building in their habitat, so in a relatively short time concrete buildings will be damaged by the action of micro and macro benthos on the coast. In addition, the corrosive sea water, so that the concrete is installed easily damaged, especially when a mixture of sand and cement are not in accordance with the technical requirements. 


\section{The level of damage to the beach and the location of the Buleleng}

Damage occurs beaches are classified into the damage that has occurred, the damage that has been and is happening, the damage is and will occur, and damage will occur. Damage to beaches that have occurred there in Penarukan Beach, Coastal KampungBugis, this beach is a rocky beach sand ramps. Damage is caused by the waves of the beach. On this beach found many of the eroded concrete building. Damage to the beach that has been and is happening there in KampungBugis, beaches with sand matter with a flat or sloping topography is used for recreation and inland used as a settlement. No visible damage is artificial concrete building that began detached due to the onslaught of ocean waves. In addition, damage beaches that are and will take place on the beach is the presence of buildings, tourism facilities which juts into the sea, so that the coastal ecosystem function does not run properly.

Waves that occur relatively large mainly occurs in the west. Based on information obtained from residents who live along the coast of Buleleng obtained information that a wave that occurred in early January 2015 to reach approximately 2 meters. The waves along with the tide, so it could reach far inland and cause a lot of damage to the housing of the population, the former harbor monument Buleleng, damage to the right end of the jetty at the mouth of TukadBuleleng. This is also shown by Korwa (2013) in his study on coastal littoral land Simaluhung tidal influence

Openness beach in Buleleng against waves from various directions resulted in a growing amount of damage to beaches along the coast of the research sites. Moreover, the absence of beach protected by a natural barrier such as mangroves that can reduce wave energy and has the function of protective artificial breakwater.Triatmojo research results in Media Techniques (1999) showed that the main factors that cause coastal erosion is a wave that strikes directly onto the beach and currents along the coast. By using the method SMK (Sverdrup MunkBredsneider) based on data from wind speed, and wind blown long distances wave drag, obtained significant results for different propagation direction of the wind in the deep sea.

Planning coastal buildings in Buleleng covers an area that stretches from the mouth to the mouth of TukadBanyumalaKubujati. The beach at this time were damaged by erosion and has not received treatment or prevention in an integrated manner. Building existing coastal protection protects only certain buildings that are considered important. On both sides of the estuary TukadBuleleng there is a jetty that serves to resist the entry of coastal sediments enter the mouth of the river. Coastline around the estuary will be strongly influenced by building a second jetty in the estuary TukadBuleleng. Jetty that is made of concrete and gabion stone Buis with a length of about 50 meters. The existence of the jetty will affect the coastline change.

\section{The role of communities in the management of coastal and beach}

Community involvement in the management of coastal and marine in the district of Buleleng is highly dependent on the level of public awareness of the importance of coastal environmental protection function. Therefore, it is necessary to increase public awareness activities gradually and continuously. Challenges or obstacles that lie ahead in awareness-raising activities Buleleng coastal communities about the management of coastal destruction, among others with community-based management of coastal destruction.In this case the role of communities in managing coastal damage by means of an ecological and the technical means to break up the tidal waves pounding the shore. It should be emphasized to the public that the mechanisms for the management of coastal destruction is a process that follows the principle of sustainability, diversity and sustainability, it takes quite a long time. It is this process that will provide the last protective function for the community and the coast.

Giving a proper understanding of coastal communities about the importance of coastal management is vital. With the right understanding, is expected to grow a sense of community, so that people want to keep and care for the environment is in the coastal territory. In addition, by directly involving rural communities in all activities relating to the management of coastal environments, such as construction activities, socialization and training, will provide a significant impact to the public awareness of the importance of community-based coastal protection function.

The need for security and a comfortable place to stay in the village located on the coast of the threat of erosion and abrasion are always lurking, the trigger for all the people that live in the coastal area of Buleleng to be actively involved in any coastal protection activities in the village. Precisely this spirit that must be protected and poured through a deal with villagers in the management of coastal and marine areas and sustainable village.

\section{CONCLUSION}

\section{Summary}

The beach in Buleleng has the following characteristics: (1) The beach is formed by marine and fluvial erosion, and (2) a process that occurs at the beach is backed by wave erosion characteristics of the coast with beach waves were not so great.Damage to beaches that have occurred there in Kubutambahan Beach, Coastal KampungBugis, and Seririt. This beach is a rocky beach, sand ramps. Damage is caused by the waves of the beach. On this beach found many of the eroded concrete building. Damage to the beach that has been and is 
happening there in KampungBugis, the beach is a sand matter with a flat or sloping topography is used for recreation and inland used as a settlement.Community involvement in the management of coastal damage by self-help ensure their sustainability, diversity and sustainability of coastal environments, in addition to growing public awareness of the importance of coastal environmental protection function.

\section{SUGGESTION}

The need for enforcement of local regulations regarding spatial coastal Regency of Buleleng, which corresponds to a distance of the border of the beach that is allowed to create a building, so the space for coastal ecosystem goes according to their functions.Needs to be done about the making of the redenomination of the physical form of a concrete terrace building to cope with the erosion of the beach by using ways that are ecologically sound.

\section{REFERENCES}

[1] Anonymous.(2002). The Bali Beach Security Project. Department Of PU Province Of Bali.

[2] Astra Wesnawa, I Gede, (2007). Land Management for Rural Indigenous community-based Housing in the province of Bali. Communication media FIS ISSN 1726-8683 vol. 6 N0. 1, April 2007, pp. 1-14.

[3] Astra Wesnawa, I Gede. (2010). Coastal damage and Handling Efforts in district of Buleleng. Research Report.UndikshaSingaraja.

[4] Astra Wesnawa, I GedePutu and IndraChristiawan, (2014). Geography Of Disasters. Graha Science: Yogyakarta.

[5] Dahuri, R., J. Rais, SP. Ginting, and MJ Sitepu.(1996). Resource Management of TheCoastalArea. PT PradnyaParamita, Jakarta.

[6] NawaSuwedi, (2006). Technology Countermeasures and Coastal damage control, the beach and sea for our support of the development of tourism.Environmental Technology Journal Vol 7 No 2 It 152-159. Jakarta in May 2006.

[7] Notohadipromo.(1978). Physical Gatra in Critical land management. In the Land of Natural Resources and Human Environment. Department of Gadjah Mada University Yogyakarta Faculty Of Agriculture Land.

[8] Sugiyono, (2016).MetodePenelitianKuantitatifKualitatifdan R\&DPenerbit :PenerbitAlfabeta

[9] YostanLahabu, Joshian NW Schadow, great B Windarta.(2015). Island Mangrove ecological Conditions MantehageWori Sub County of North Minahasa in North Sulawesi province. Journal of coastal and Tropical Sea.Vo. 2.No 1 (2015) it 41-48.

[10] Salvatore a'PauloNarahawarin, RignoldaDjamaludin, PA.Angmalisang.(2013). The characteristics of the Currents in the waters around the area KelurahanSarioTumpaanMando Bay. Journal of Coastal and Tropical Sea.Vo. 2.No 1 (2013) terms of 13-17.

[11] Triatmodjo.B. (1999).Coastal Engineering. Beta Offset Yogyakarta. 